
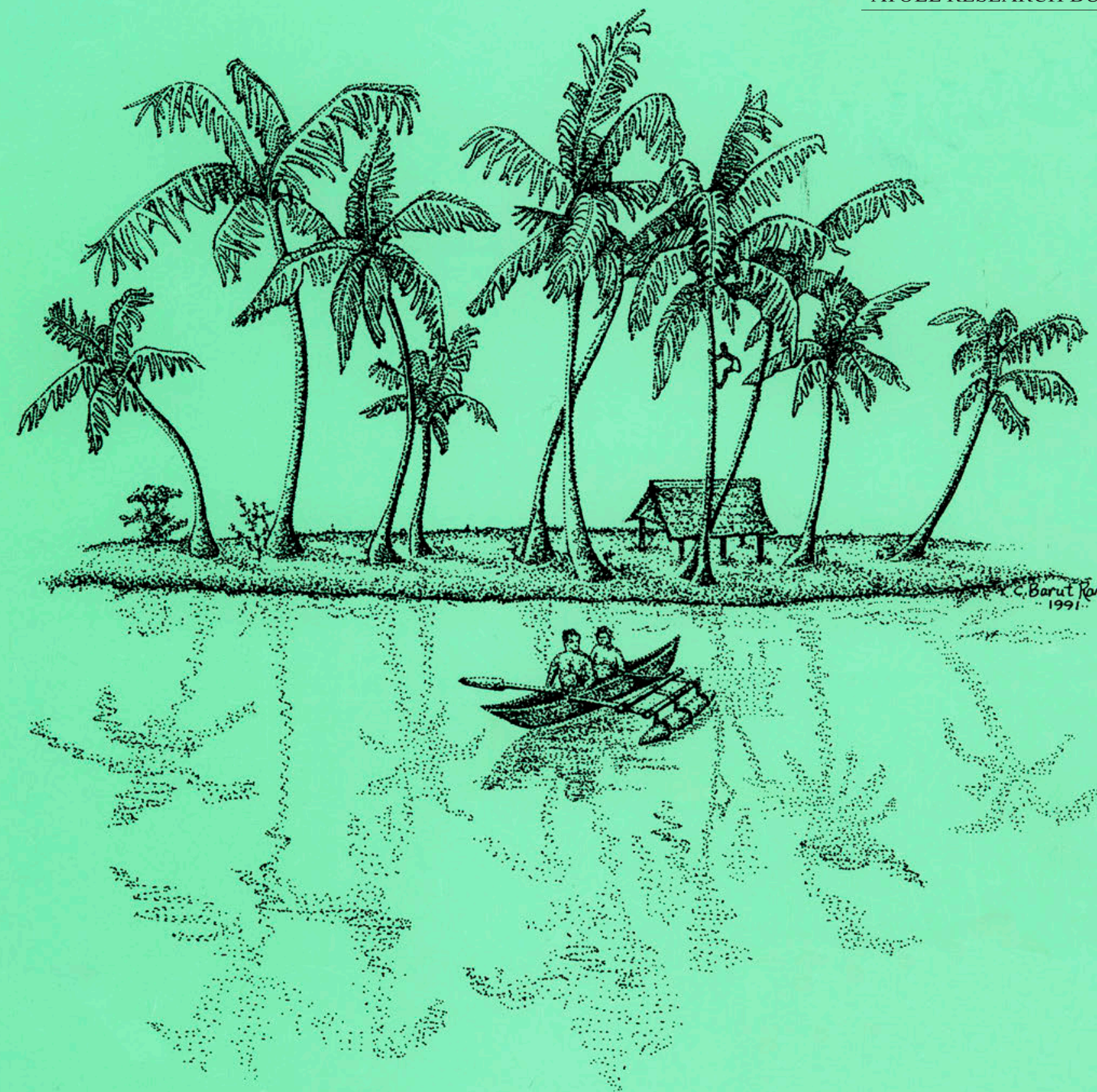

MANUAL ACOUSTIC TRACKING REVEALS THE SPATIAL ECOLOGY OF GIANT TREVALLY

AT A REMOTE SOUTH PACIFIC ATOLL, WITH IMPLICATIONS FOR THEIR MANAGEMENT

Alexander Filous, Robert J. Lennox,

Andy J. Danylchuk, and Alan M. Friedlander

RESEARCH 



\title{
MANUAL ACOUSTIC TRACKING REVEALS THE SPATIAL ECOLOGY OF GIANT TREVALLY AT A REMOTE SOUTH PACIFIC ATOLL, WITH IMPLICATIONS FOR THEIR MANAGEMENT
}

\author{
Alexander Filous, Robert J. Lennox, \\ Andy J. Danylchuk, and Alan M. Friedlander
}

Atoll Research Bulletin No. 625 13 September 2019

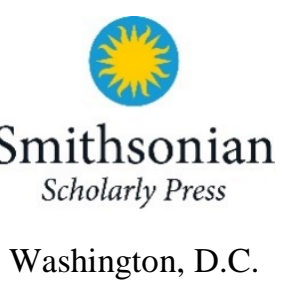


All statements made in papers published in the Atoll Research Bulletin are the sole responsibility of the authors and do not necessarily represent the views of the Smithsonian Institution or of the editors of the bulletin. Articles submitted for publication in the Atoll Research Bulletin should be original papers and must be made available by authors for open access publication under a CC-BY-NC license. Manuscripts should be consistent with the "Author Formatting Guidelines for Publication in the Atoll Research Bulletin.” All submissions to the bulletin are peer reviewed and, after revision, are evaluated prior to acceptance and publication through the publisher's open access portal (https://smithsonian.figshare.com/ScholarlyPress).

Published by SMITHSONIAN INSTITUTION SCHOLARLY PRESS

P.O. Box 37012, MRC 957

Washington, D.C. 20013-7012

https://scholarlypress.si.edu/

ISSN: 0077-5630 (online)

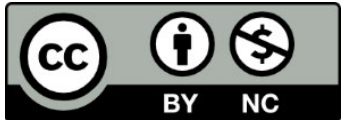

This work is licensed under a Creative Commons Attribution-NonCommercial 4.0 International License. 


\section{CONTENTS}

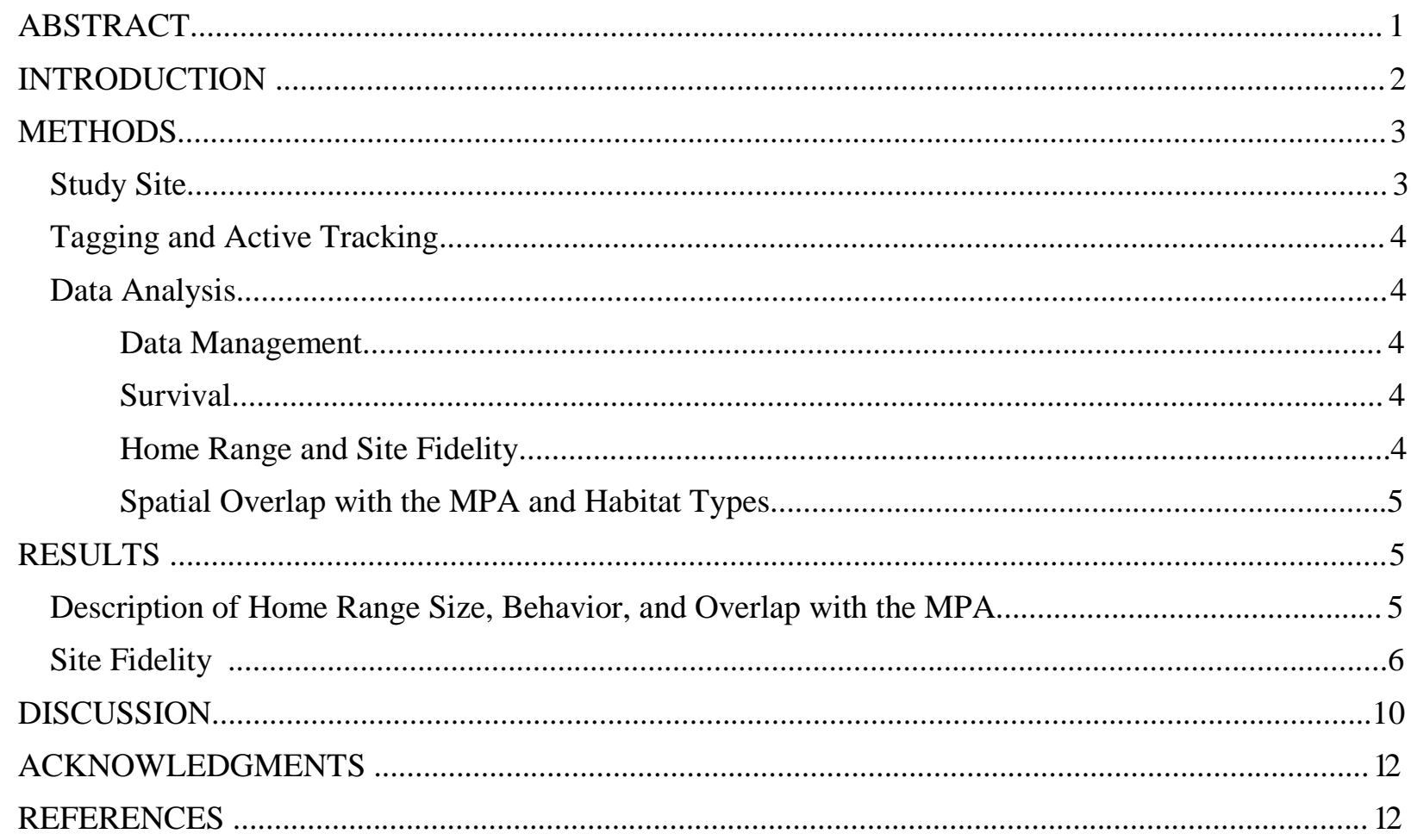





\title{
MANUAL ACOUSTIC TRACKING REVEALS THE SPATIAL ECOLOGY OF GIANT TREVALLY AT A REMOTE SOUTH PACIFIC ATOLL, WITH IMPLICATIONS FOR THEIR MANAGEMENT
}

\author{
ALEXANDER FILOUS ${ }^{1,3 *}$, ROBERT J. LENNOX ${ }^{2}$, \\ ANDY J. DANYLCHUK ${ }^{1}$, and ALAN M. FRIEDLANDER ${ }^{3,4}$
}

\begin{abstract}
Giant trevally (Caranx ignobilis) are important predators on the reefs of the tropical Indo-Pacific and research into their spatial ecology is needed to improve our understanding of their behavior and assist fisheries management. We used active acoustic telemetry to describe the fine-scale movements of giant trevally at Tetiaroa Atoll, including their home range, site fidelity, habitat use and spatial overlap with a small (21 $\left.\mathrm{km}^{2}\right)$ Marine Protected Area (MPA). The home ranges of giant trevally were small but varied among individuals (Minimum Convex Polygon $\bar{X}=3.2 \pm 2.5 \mathrm{~km}^{2}$ ). All giant trevally exhibited site fidelity to their respective home ranges with a 31\% average overlap in daily space use, but there was limited overlap in home ranges among individuals, with intra-individual spatial overlap significantly greater than inter-individual overlap $(\mathrm{t}=$ -4.93 , $\mathrm{df}=16.87$, p-value $=<0.001)$. There was only modest overlap $(19 \pm 19 \%)$ of giant trevally home ranges within the MPA and high spatial overlap of home ranges with deep lagoon habitats (90 $\pm 0.09 \%)$. Our results indicate that MPAs could be an effective tool for the conservation of this species if they are implemented on an atoll-wide scale. However, in the case of managing recreational catch-and-release fisheries, rotational smallscale temporal closures could be effective in regulating the angling pressure imposed upon giant trevally, provided post-release mortality is minimized. The results of this study provide the first detailed account of habitat use in this species and highlight the need for additional research on the factors contributing to the survival of caught-and-released giant trevally in predator dominated atolls, especially as their popularity as a target of recreational fisheries continues to grow, and fishing operations and agencies are faced with the need to manage their fisheries.
\end{abstract}

Key words: Giant trevally (Caranx ignobilis), Marine Protected Area, home range, acoustic telemetry

1 Department of Environmental Conservation, University of Massachusetts Amherst, 160 Holdsworth Way, Amherst, MA 01003-9485 USA

${ }^{2}$ Fish Ecology and Conservation Physiology Laboratory, Department of Biology, Carleton University, Ottawa, Ontario, Canada K1S 5B6

${ }^{3}$ Fisheries Ecology Research Lab, Department of Biology, University of Hawaii at Manoa, Honolulu, HI 96822

${ }^{4}$ Pristine Seas, National Geographic Society, Washington, DC.

*Corresponding author: afilous@umass.edu; 415-999-0763; fax: 650-692-1564 


\section{INTRODUCTION}

Giant trevally (Caranx ignobilis) are important predators on the reefs of the tropical Indo-Pacific (Randall 2005). Revered for their strength and aggressive nature, the quest for giant trevally on the shallow water flats of remote atolls is for many recreational anglers the pinnacle of saltwater fishing (McLeod 2016). As a result, giant trevally have become a popular target for recreational anglers and their populations now support recreational fishing tourism throughout their range (McLeod 2016). In addition to their importance to recreational fisheries, these predators play an equally important role in maintaining the balance of coral reef ecosystems by imposing a top down effect on lower trophic groups (Sudekum et al. 1991). In parts of their distribution where commercial fisheries actively target giant trevally, their numbers have been reduced to a fraction of their historical abundance and they are nearly extirpated from many of these costal ecosystems (Friedlander and DeMartini 2002; Friedlander et al. 2015). Large predators like trevally are likely to have a cascading effect on the behavior and abundance of their prey and competitors (Hammerschlag et al. 2015), and thus impacts to these predators have the potential to alter the function of the entire ecosystem (Friedlander and DeMartini 2002; Heithaus et al. 2008).

Considering the importance of giant trevally to fisheries and coral reef ecosystems, research on their spatial ecology, specifically their movements, site fidelity and home range is needed to inform the management of their fisheries. The home range of an organism encompasses the spatially and temporally defined area in which an animal lives and periodically travels while engaged in its normal activities, including foraging and the maintenance of homeostasis (Burt 1943; Börger et al. 2008; Morrissey et al. 2009). Detailed information on the size of home ranges and movements away from them can assist in the management of fisheries by informing the design and efficacy of Marine Protected Areas (MPAs) to ensure that they are appropriately located and sized. Additionally, this information can elucidate critical habitats that should be protected from anthropogenic development, identify a species' risk of contaminant exposure and help identify other spatial/temporal conservation actions such as seasonal closures in spawning aggregation sites, to preserve the quality of a fishery (Roberts and Polunin 1991; Kramer and Chapman 1999; Roberts et al. 2002; Sale et al. 2005; Moffitt et al. 2009; Grüss et al. 2011; Wolfe and Lowe 2015).

Both active and passive acoustic telemetry have been widely implemented to study the movement, behavior and home range of marine fishes (Heupel et al. 2006; Meyer et al. 2007a; Papastamatiou et al. 2009, 2010), and as a result have become important tools in developing species-specific spatial management (Donaldson et al. 2014; Crossin et al. 2017; Lennox et al. 2018). Active acoustic telemetry involves outfitting a fish with an acoustic transmitter capable of emitting a signal at a short and continuous interval. This signal indicates a fish's location and is decoded by a hydrophone permitting a fish to be precisely positioned for long periods, allowing for a nearly continuous record of daily movements (Voegeli et al. 2001). Detailed time series of individual positions provide information about the habitat preferences, home range, and behavior of an animal across short time scales (Meyer and Holland 2005; Papastamatiou et al. 2009). In contrast, passive acoustic telemetry involves tagging fish with a coded transmitter and provides a record of a fish's presence or absence in a fixed array of acoustic receivers. The passive methodology allows for an investigation of longterm movement patterns beyond the capabilities of active tracking but lacks the spatial and temporal resolution provided by active tracking (Voegeli et al. 2001). However recent advances in tracking technologies have improved the spatial precision from passive monitoring arrays with Vemco Positioning Systems (VPS), but are expensive and require more resources than traditional monitoring (Andrews et al. 2011; Espinoza et al. 2011).

The broad-scale movements of giant trevally have been studied with passive acoustic telemetry (Meyer et al. 2007b; Lédée et al. 2015; Filous et al. 2017a); these studies suggest that giant trevally exhibit site fidelity to core areas on isolated islands and atolls. However, in these studies giant trevally periodically moved outside of acoustic arrays, and average residency index's ranged from 50 to 53 percent with large scale trans-atoll and in some cases intra-island movements observed (Meyer et al. 2007b; Lédée et al. 2015; Filous et al. 2017a). The presence-absence data obtained from the movements of this species in these fixed arrays leaves gaps in our understanding of the extent of their daily space use and behavior. Active tracking is labor intensive but provides fine-scale data necessary to fill the knowledge gaps in the spatial ecology of this species (Meyer and 
Holland 2005; Afonso et al. 2009; Papastamatiou et al. 2009). Yet, apart from one study on the movements of juveniles, little research has been conducted to evaluate the fine-scale movements of adult giant trevally (Wetherbee et al. 2004). The objectives of this work were to utilize active acoustic telemetry to describe the natural movements and behavior of giant trevally including their home range size, site fidelity, habitat use and spatial overlap with a small MPA. Here, we present the first description of the fine-scale movements of this species in a remote South Pacific atoll, the results of which will contribute to the conservation of this species as their popularity continues to grow and fishing operations and agencies are faced with the need to manage their fisheries.

\section{METHODS}

\section{Study Site}

Tetiaroa is a closed atoll in the Society Islands, $53 \mathrm{~km}$ north of Tahiti, in French Polynesia. The atoll is comprised of 12 motu, small islands, encircling shallow sand flats around a lagoon that descends to a maximum depth of $30 \mathrm{~m}$ and is characterized by sand and silt substrate with scattered coral pinnacles. The atoll supports a recreational fishery in which visiting anglers target giant trevally, bonefish (Albula glossodonta) and other reef-associated species. Additionally, a small MPA $\left(21 \mathrm{~km}^{2}\right)$ divides the center of the atoll longitudinally, effectively restricting the harvest or interaction with marine life in the southern half of the lagoon. Fishing is permitted in the northern part of the atoll, however, netting and spearfishing at night are prohibited throughout its interior (Figure 1).

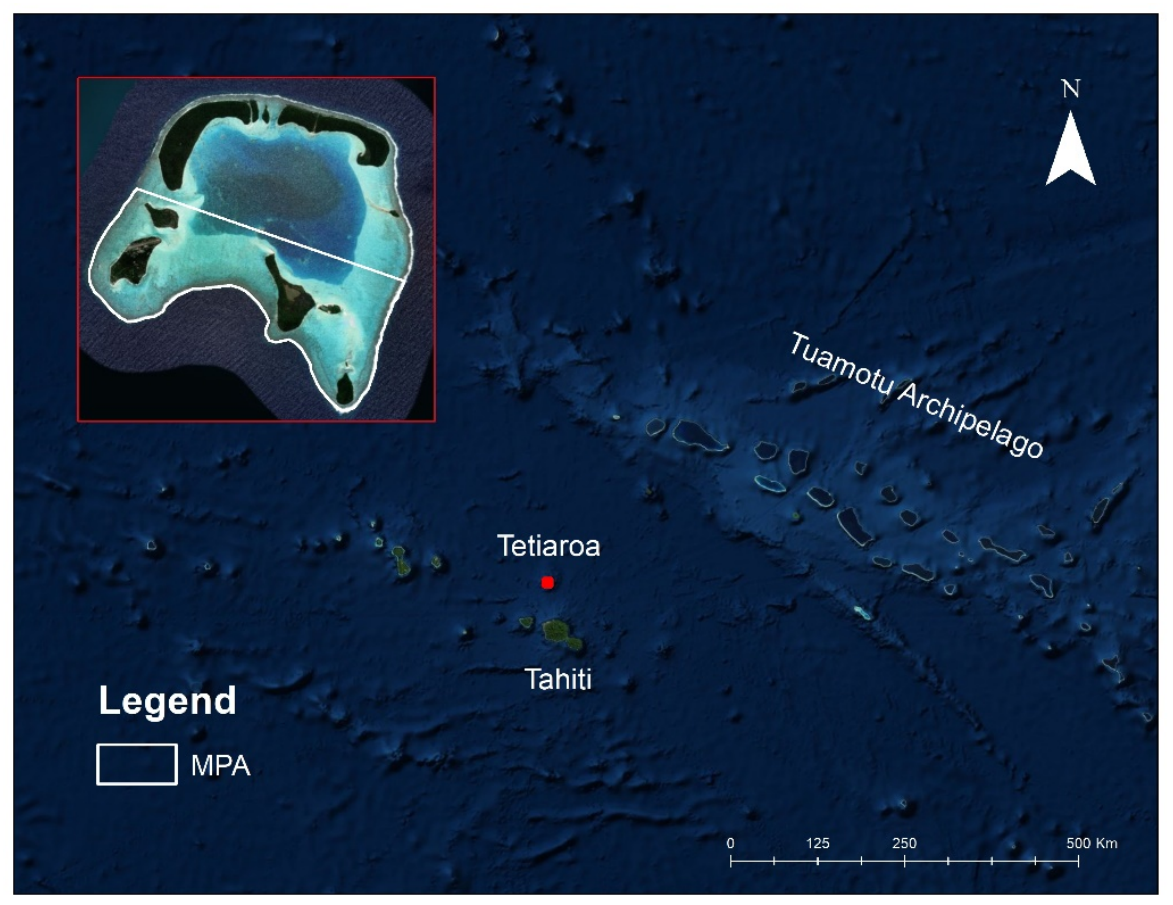

Figure 1. The location of Tetiaroa Atoll in French Polynesia, with its MPA designated by the white polygon. 


\section{Tagging and Active Tracking}

Giant trevally were captured with fly-fishing equipment in the sector of Tetiaroa's lagoon that is open to fishing. Angling was carried out with 12-weight fly rods, 80-100lb fluorocarbon leaders, and flies tied on single 4/0 barbless hooks. Upon capture, all giant trevally were brought on board the research vessel and placed on a padded surgical mat with a hose circulating sea water over their gills. Each fish was measured in fork length (FL cm) and surgically fitted with a V13-1L continuous acoustic transmitter (13 x 45 mm, Vemco, Halifax, Nova Scotia). Transmitters were surgically implanted into the body cavity of each animal through a $2 \mathrm{~cm}$ incision in the abdominal wall and closed with an interrupted nylon suture (Holland et al. 1999; Meyer and Honebrink 2005). The V13 continuous tags were programmed to transmit a single pulse at a unique frequency $(65-70 \mathrm{kHz})$ every second for up to $30 \mathrm{~d}$ for individual identification. After release, all transmitters were located using a VR100 acoustic receiver (Vemco, Halifax, Nova Scotia).

Following surgery, fish were returned to the water, revived on a shallow sand flat and released after showing signs of increased vigor. After $96 \mathrm{~h}$ we resumed tracking these fish by systematically searching the lagoon from randomly selected locations, and upon recovery their diurnal movements were monitored to obtain estimates of daytime home range size and behavior. Although we were able to decode all fish simultaneously, we were only able to track a single fish at a given time. Nonetheless, we noted the presence and location of other fish when they were within range. During tracking events the behavior of giant trevally and their interactions with other marine life was visibly observed and photographed.

\section{Data Analysis}

\section{Data Management}

Data were filtered to ensure that at the time of detection a tracked fish was in proximity to the GPS locations recoded by the VR100 by excluding any detections less than $70 \mathrm{~dB}$ in signal strength.

\section{Survival}

To determine the survival of each fish, we observed tagged fish during tracking events and evaluated their survival based on the criteria that: (1) the fish was relocated and tracked at a minimum of two weeks after initial capture and release, and (2) each fish was observed during these later tracking events to ensure that the animal being tracked was still the instrumented animal and not a predator or scavenger that had assumed the tag of a giant trevally (Gibson et al. 2015).

\section{Home Range and Site Fidelity}

To describe the home range and site fidelity of giant trevally, the tracks of each fish were plotted in ArcGIS 10.2 (ESRI) and the size and location of their individual home ranges were estimated using three metrics: the minimum convex polygon (MCP), the 95\% kernel utilization distribution (KUD), and the 50\% KUD. The MCP is the area of the polygon formed when connecting the outer positions of a tracked fish (Heupel et al. 2004) and provides a measure of the size of this area. The 95\% KUD is a probability distribution that provides a measure of space use within which there is a 95\% probability of re-sighting an individual. This measure is considered the home range of an individual and similarly, a 50\% KUD represents the area where there is a $50 \%$ chance of finding an individual and represents an area of core use (Heupel et al. 2004; Papastamatiou et al. 2009). To measure an individual's entire home range, we calculated these metrics from all their recorded geographic locations during the study. These polygons and their areas were calculated with the mcp and kernelUD functions in the adehabitatHR package in $\mathrm{R}$ and visualized in ArcGIS 10.2 (ESRI).

To evaluate site fidelity exhibited by individual fish, we calculated the MCP of each fish's daily tracks following the methods described above and calculated the Index of Refuge (IOR) between tracks of equivalent monitoring time. 


$$
\mathrm{IOR}=[\mathrm{OV}(\mathrm{A} 1+\mathrm{A} 2)] /(\mathrm{A} 1+\mathrm{A} 2)
$$

IOR, the index of refuge, [OV (A1+A2)], is the area of overlap between two daily home ranges, $(\mathrm{A} 1+\mathrm{A} 2)$ total area of both home ranges. A value of 0 indicates no overlap of use, and a measure of 1 indicating 100 percent overlap of use (Papastamatiou et al. 2009).

We calculated the location and size of the MCP for each daily fish track with the mcp function in the adehabitatHR package and calculated the area of overlap between tracks with the gIntersection function in the rgeos package in $\mathrm{R}$. We then used linear regression to test for a relationship between fish size and daily IOR using the $\mathrm{lm}$ function in R. Finally, to examine intra-individual overlap and determine whether giant trevally exhibit spatial overlap in home range among conspecifics (Morrissey et al. 2009), we calculated the IOR of the total MCPs of each giant trevally against each other to describe the overlap of home ranges and evaluate inter-individual space use following the methods described above. We then tested for a difference between intra-individual and inter-individual IOR with a Welch Two Sample t-test with the t.test function in R, a test of the hypothesis that range use was independent of the individual.

\section{Spatial Overlap with the MPA and Habitat Types}

To evaluate the extent to which the atoll's MPA provides protection to giant trevally, we calculated the spatial overlap between the MCP of each tracked fish and the area of the MPA. The area of overlap was estimated with the gIntersection function in the rgeos package in $\mathrm{R}$, and these overlapping areas were converted to percentages of giant trevally home range by dividing the area of overlap with total home range area to evaluate whether giant trevally space use was independent of the protections afforded by the protected area designation. This process was replicated to describe their habitat preferences by calculating the percentages of home range overlap with the deep lagoon and shallow water sand flats, the two dominant habitat types in the interior of Tetiaroa Atoll.

\section{RESULTS}

Between August 8 and October 23, 2014, we tagged and tracked five adult C. ignobilis with V13-1L continuous transmitters ranging in size from 79 to $90(83.8 \pm 4.5 \mathrm{sd}) \mathrm{cm}$ FL. The movements of these five fish were monitored from 20 to $71 \mathrm{~h}$ across periods spanning 32 to $42 \mathrm{~d}$, with a total of $233 \mathrm{~h}$ of giant trevally observations (Table 1).

\section{Description of Home Range Size, Behavior, and Overlap with the MPA}

The home range size of giant trevally was small but variable among individuals, with estimates of their MCPs ranging from 0.7 to $8 \mathrm{~km}^{2}$ and a mean of $3.2 \pm 2.5 \mathrm{SD} \mathrm{km}{ }^{2}$ (Figure 2). The $95 \%$ KUDs ranged in size from 1 to $10.3 \mathrm{~km}^{2}$ with a mean of $4.1 \pm 3.3 \mathrm{SD} \mathrm{km}$. Areas of core use ranged from 0.1 to $2.6 \mathrm{~km}^{2}$ and averaged $1.1 \mathrm{~km}^{2}$ within the lagoon (Table 1). The overlap of giant trevally home range with Teriaroa's MPA ranged from 0 to $52 \%$ with an average of $19 \pm 19$ SD \% and giant trevally space use predominantly overlapped with deeper lagoon habitat, which comprised from 75\% to 99\% (90 \pm 0.09 SD) of their home ranges (Table 1).

The giant trevally with the largest home range, CAIG5, used $8 \mathrm{~km}^{2}$ of the lagoon (Figure 3). After recovery from tagging, we tracked this fish on three separate occasions and found that it consistently traversed the lagoon. During each tracking event, this individual began the day at the lagoon's edge on the western portion of the atoll and moved east completing its day on the sand flats at the eastern part of the atoll. The home range of this fish had a 28\% overlap with the MPA. The giant trevally with the second largest home range was CAIG4, which we monitored on five separate days where it utilized $3 \mathrm{~km}^{2}$ of lagoon 
Table 1. The size, monitoring information, home range estimations, and spatial overlap with the Marine Protected Area (MPA) for giant trevally at Tetiaroa Atoll.

\begin{tabular}{cccccccccccc}
\hline Fish ID & $\begin{array}{c}\text { Fork } \\
\text { length } \\
(\mathrm{cm})\end{array}$ & $\begin{array}{c}\text { Detection } \\
\text { Span } \\
(\text { days })\end{array}$ & $\begin{array}{c}\text { Days } \\
\text { detected }\end{array}$ & $\begin{array}{c}\text { Hours } \\
\text { Monitored }\end{array}$ & $\begin{array}{c}\text { MCP } \\
\left(\mathrm{km}^{2}\right)\end{array}$ & $\begin{array}{c}95 \% \\
\text { KUD } \\
\left(\mathrm{km}^{2}\right)\end{array}$ & $\begin{array}{c}50 \% \\
\text { KUD } \\
\left(\mathrm{km}^{2}\right)\end{array}$ & $\begin{array}{c}\% \\
\text { overlap } \\
\text { with } \\
\text { MPA }\end{array}$ & $\begin{array}{c}\% \\
\text { overlap } \\
\text { with } \\
\text { lagoon }\end{array}$ & $\begin{array}{c}\% \\
\text { overlap } \\
\text { with } \\
\text { flats }\end{array}$ \\
\hline CAIG1 & 83 & 44 & 4 & 20 & 0.7 & 1 & 0.1 & 52 & 92 & 8 \\
CAIG2 & 90 & 32 & 7 & 43 & 1.3 & 2.2 & 0.6 & 0 & 99 & 1 \\
CAIG3 & 79 & 39 & 18 & 71 & 2.8 & 3.5 & 1 & 16 & 86 & 14 \\
CAIG4 & 88 & 37 & 15 & 62 & 3 & 3.3 & 0.9 & 0 & 98 & 2 \\
CAIG5 & 79 & 41 & 10 & 37 & 8 & 10.3 & 2.6 & 28 & 75 & 25 \\
\hline Mean \pm sd & $83.8 \pm 4.5$ & $38.6 \pm 4.0$ & $10.8 \pm 5.11$ & $46.6 \pm 18.1$ & $3.2 \pm 2.5$ & $4.1 \pm 3.3$ & $1.1 \pm 0.8$ & $19 \pm 19$ & $90 \pm 0.09$ & $10 \pm 0.09$ \\
\hline
\end{tabular}

habitat. The movements of this fish remained restricted to the northern sector of the atoll and exhibited $0 \%$ overlap with the MPA (Figure 3).

CAIG3 was monitored for a total of $71 \mathrm{~h}$ and was detected within its home range $100 \%$ of the time we surveyed the eastern part of the lagoon, which suggests that this fish exhibits strong site fidelity to the eastern drop off (Figure 3). This fish spent the majority of its time making a circuit, traveling north and south along the lagoon's eastern slope and exhibiting a 16\% overlap with the MPA, repeatedly crossing its boundary. This individual utilized a home range $\left(2.8 \mathrm{~km}^{2}\right)$ similar to CAIG4 and the animal's core use area (50\% KUD) coincided with the southern part of the eastern drop off. The only time the fish was observed away from this area was while it made periodic visits to the central lagoon or while it was observed on the flats adjacent to the eastern drop off swimming in association with sting rays (Himantura fai). This association between giant trevally and sting rays was observed in three of the five individuals we tracked with some individual giant trevally spending up to $2 \mathrm{~h}$ swimming and feeding in association with these rays (Figure 4). The smallest recorded home ranges were 0.7 (CAIG1) and $1.3 \mathrm{~km}^{2}$ (CAIG2), however, these figures likely underestimate the size of these fish's home range, as both individuals made repeated and predictable excursions from the lagoon to the reefs edge and we were unable to obtain complete coverage of their space use (Figure 2; Table 1).

\section{Site Fidelity}

Despite the variation in home range size, the movements of each fish within their home ranges were spatially and temporally repeatable within individuals. IOR results indicate that all fish exhibited site fidelity to their respective home ranges with an average overlap in daily in space use of 31\% ( \pm 9, range: 15-41\%). These values suggest this species exhibits relatively high site fidelity considering the mobility of this species. However, there was a not a significant relationship between fish size and daily IOR $\left(F_{1,7}, p=0.6\right)$, which may be due to the limited size range of the fish we tracked. The mean intra-individual spatial overlap (31\%) was significantly higher than the mean $(9 \%)$ inter-individual IOR $(\mathrm{t}=-4.93, \mathrm{df}=16.87, \mathrm{p}=0.0001$; Figure 5). 


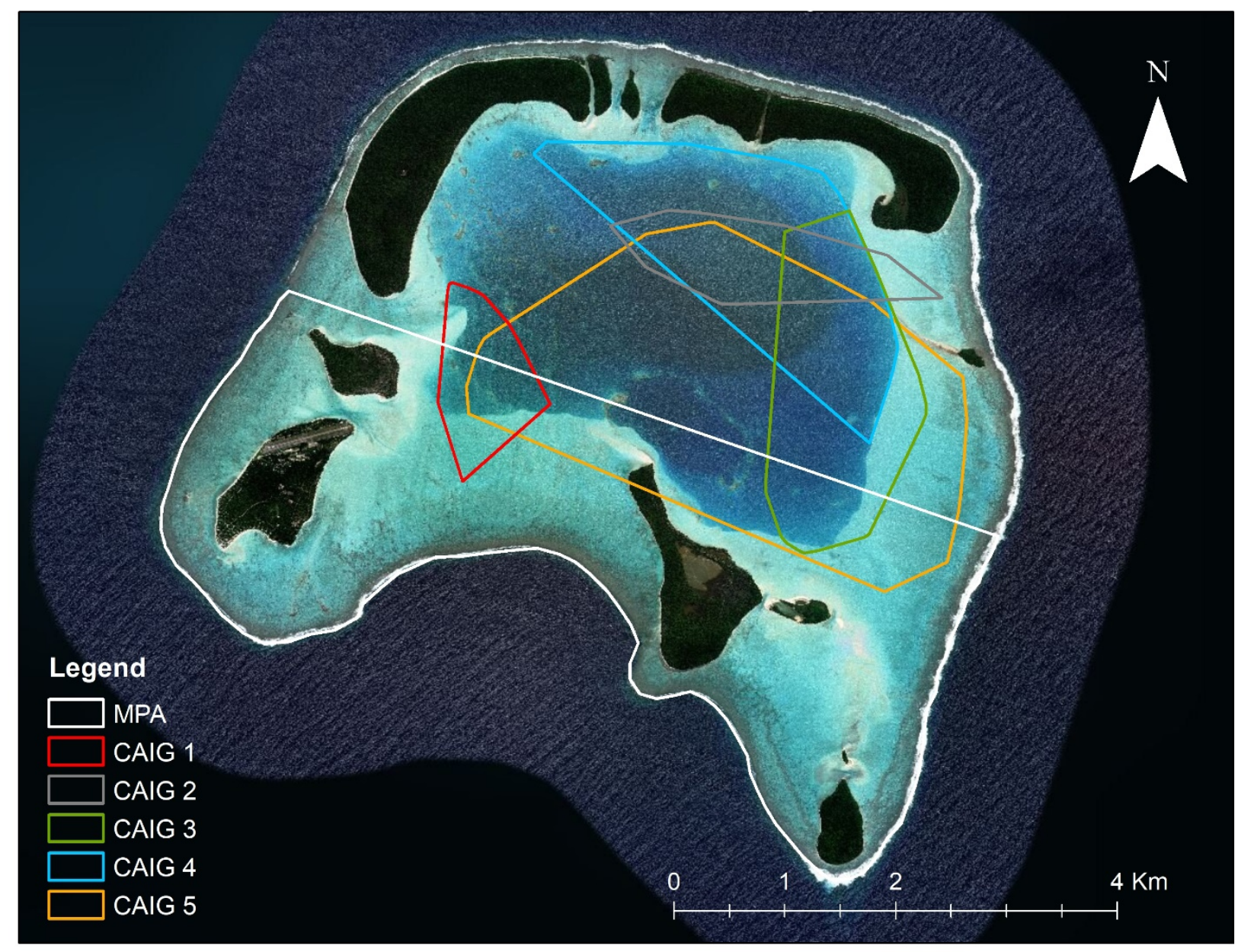

Figure 2. Tetitaroa Atoll with its MPA designated by the white polygon and the Minimum Convex Polygons (MCP), indicating the size and location of giant trevally home ranges observed during the study. 


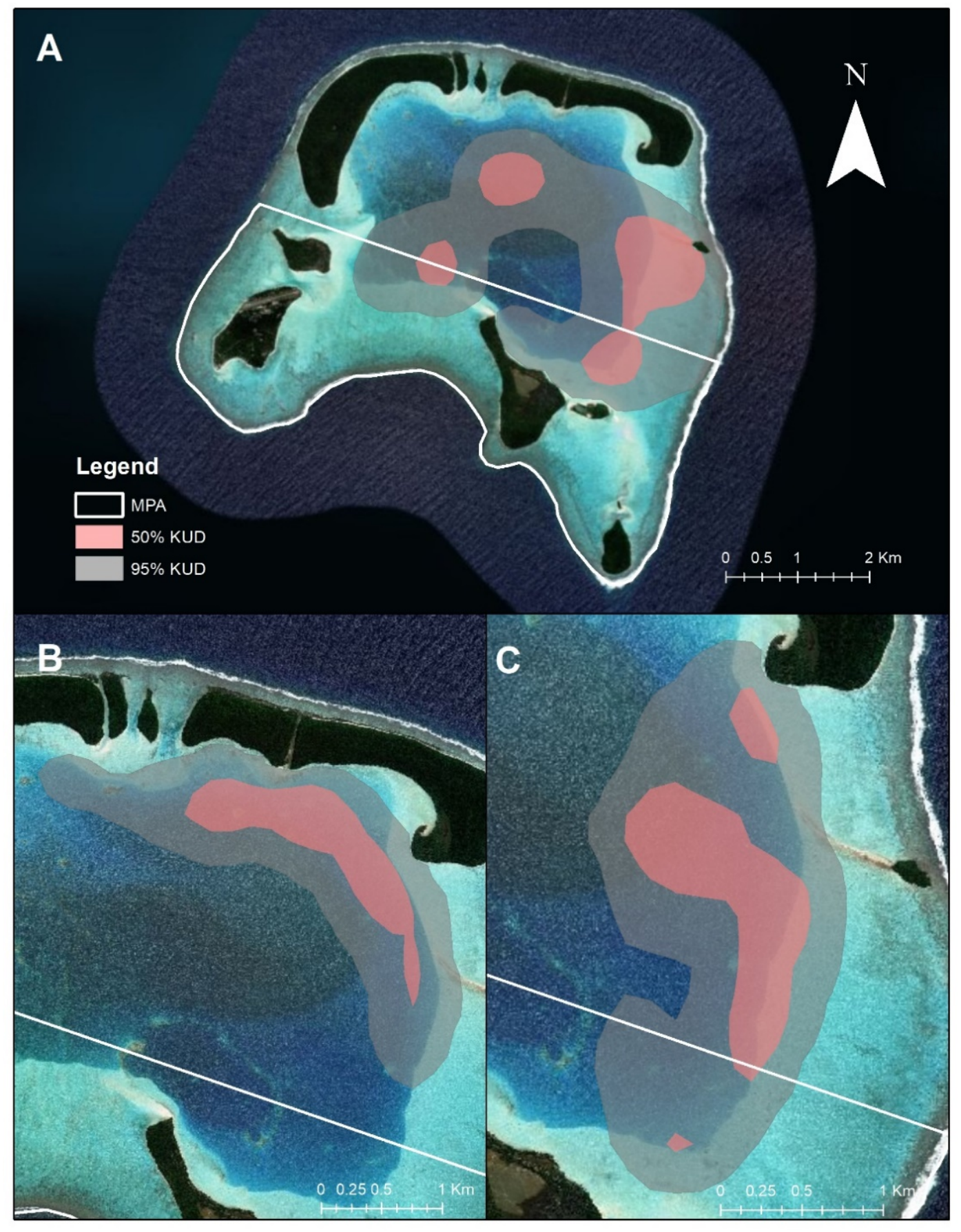

Figure 3. Tetitaroa Atoll with the Kernel Density Distributions (KUD) of CAIG5 (A), CAIG4 (B), and CAIG3 (C). Their respective 95\% KUDs are indicated by grey shading, while their $50 \%$ KUDs are indicated by red shading, and the MPA is designated by the white polygon that encompasses the southern half of Tetiaroa's lagoon. 

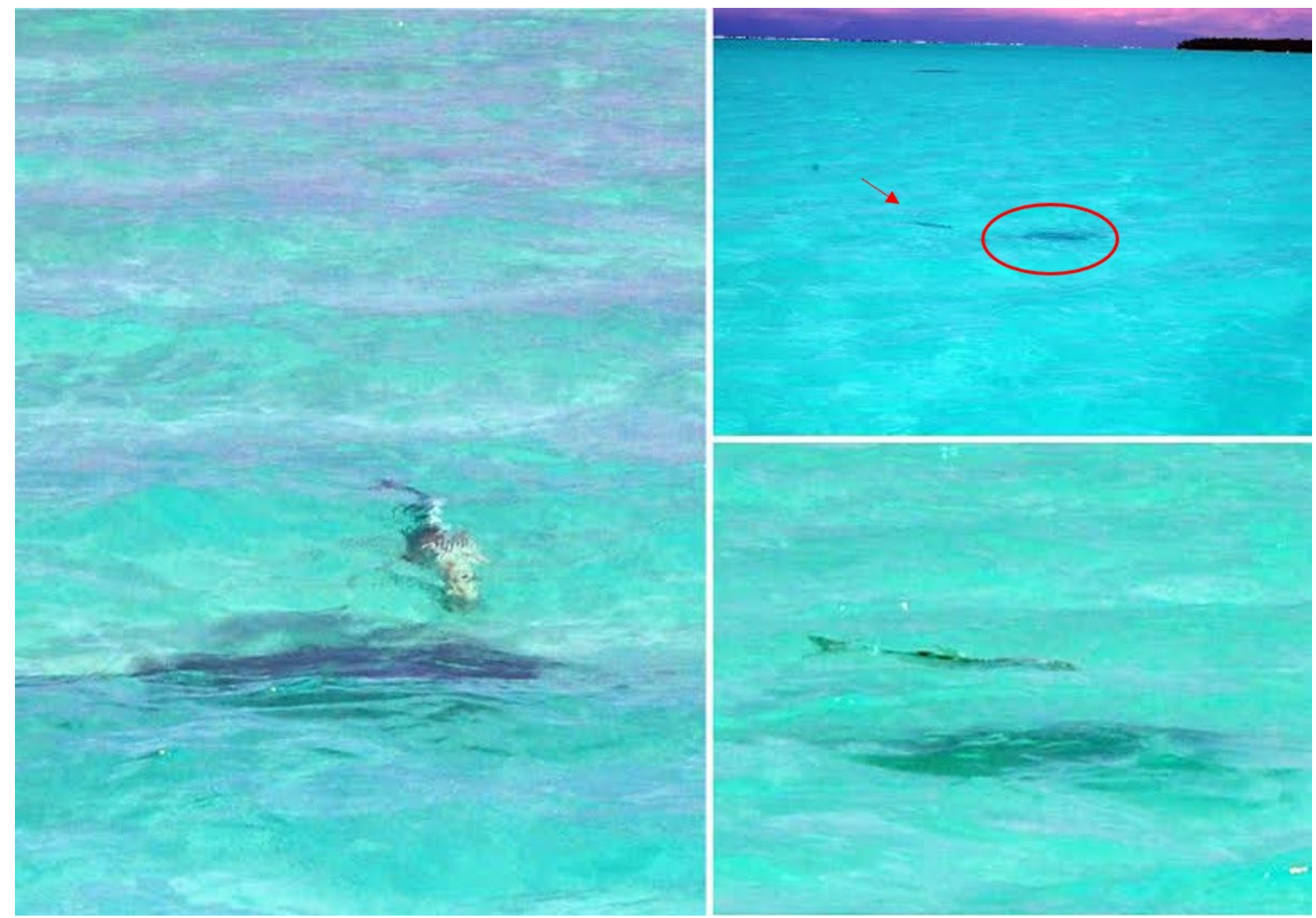

Figure 4. Images of CAIG3 hunting is association with a sting ray (Himantura fai), on the flats located in the Eastern side of Tetiaroa atoll. The red arrow indicates the position of the giant trevally and red circle highlights the sting ray. 


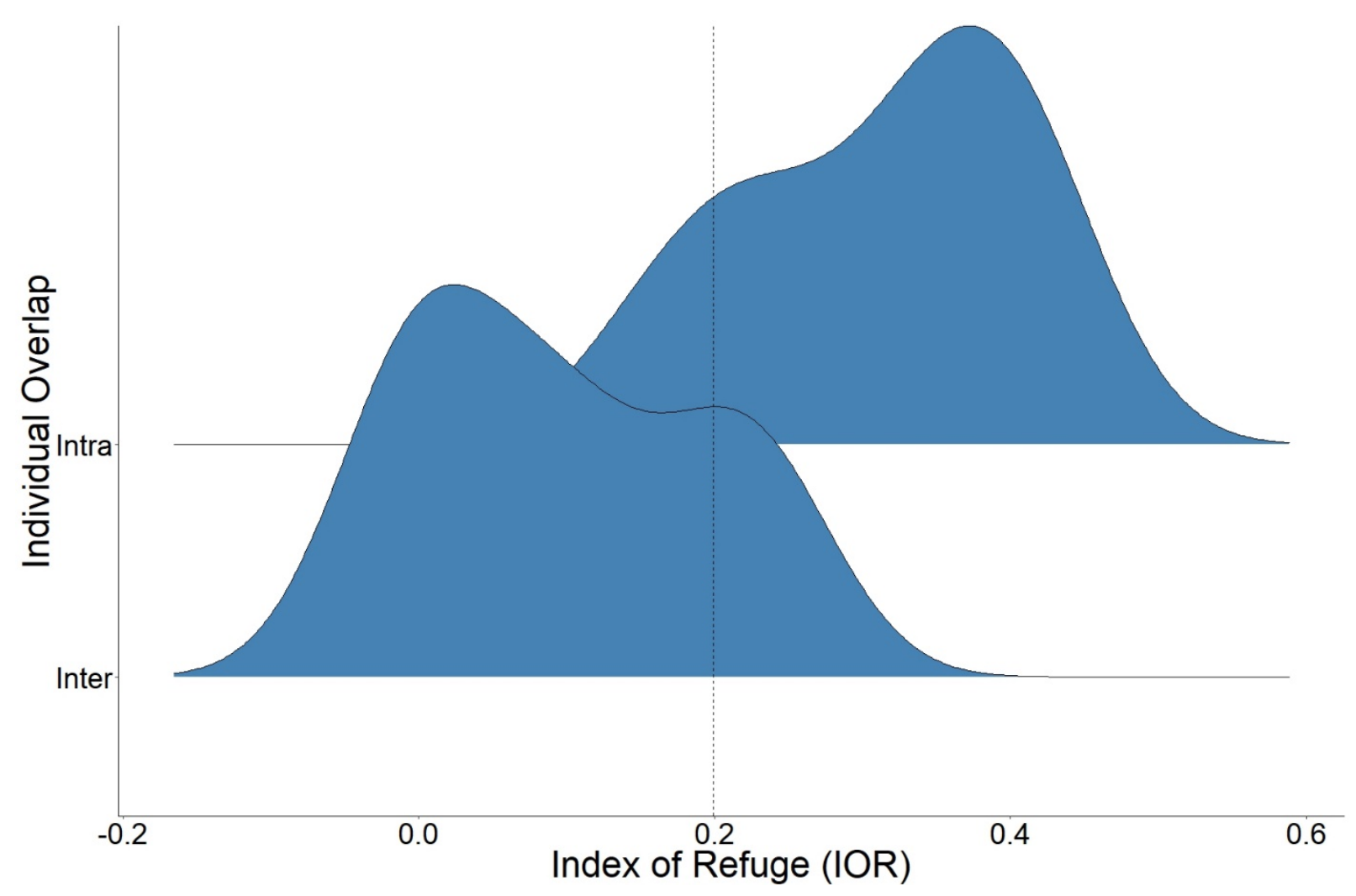

Figure 5. The density distributions of Intra-individual and Inter-individual spatial overlap in space use, with black vertical dashed line indicating the mean $(\mathrm{t}=-4.9317, \mathrm{df}=16.866$, $\mathrm{p}$-value $=0.0001)$.

\section{DISCUSSION}

An understanding of giant trevally spatial ecology is important to designing effective fisheries management plans and this research provides a unique high-resolution perspective of the behavior and movement of this species. Our results indicate, that at the time scale of this study (i.e., 32 to 44 days), giant trevally exhibit repetitive spatial and temporal patterns of habitat use. Each fish had a well-defined home range and exhibited behavior that qualitatively and quantitatively suggest they exhibit site fidelity (Cooper 1978). However, the comparison of inter-individual and intra-individual overlap in space use suggests that despite the small size of the atoll, there is only moderate overlap in the home ranges of giant trevally. The drop off along the eastern perimeter of the lagoon was the only region with high overlap in giant trevally home ranges, as it was periodically utilized by four of the five giant trevally we studied. The use of transition zones between habitats for feeding is a common behavior in other top-predators and our observations of giant trevally behavior were consistent with the space use of sharks in analogous marine systems (Heithaus et al. 2006; Papastamatiou et al. 2009). The limited degree of intra-individual overlap suggests that competitive exclusion within the species may drive giant trevally to different behavioral types in their daily foraging routines (Hardin 1960). During instances in which giant trevally were observed swimming together, there was no evidence of site defense between conspecifics, which suggests that differential home ranges is not due to territoriality (Brown and Orians 1970), but rather resource partitioning in crowded coral reef communities (Sale 2006; Ross 2018). On the shallow sand flats, giant trevally were commonly observed swimming in association with sting rays for extended periods of time; these fish were often feeding, and our observations suggest that hunting giant trevally take advantage of the rays acute sensory system, which is adapted to find small organisms hiding in the sand, but it is unclear whether this relationship is parasitism or commensalism (Losey 1978). These joint hunting or 
following relationships are common in marine trophic systems and presumably the collective foraging and or kleptoparasitism that occurs increases the fitness of the predators involved in the interaction (Karplus 1978; Ormond 1980; Strand 1988).

Acoustic telemetry has become an important tool for marine spatial planning and evaluating the efficacy of MPA's (Lennox et al. 2018). Our results suggest the current MPA at Tetiaroa offers limited protection to this mobile species from extractive fisheries, illustrated by the fact that several giant trevally home ranges were not included or individuals regularly traversed the MPA boundaries (Grüss et al. 2011). These findings in adult giant trevally were comparable to Wetherbee et al. (2004), who observed well defined home ranges of juvenile giant trevally monitored with active acoustic telemetry and limited overlap with a very small MPA $\left(0.3 \mathrm{~km}^{2}\right)$ in Hawaii. However, it should be noted that the relatively small core use areas suggest small MPA's could be effective in offering partial protection to this species. The high spatial overlap of giant trevally home range with the deeper lagoon indicates that in atoll environments this habitat must be incorporated into MPAs for them to be effective in protecting this species, with particular attention to the transition zone between the deep lagoon and shallow flats described above, as giant trevally core use coincided with the interface between these two habitat types. Giant trevally preference for deep lagoon habitats may drive the limited use of the MPA as only $15 \%$ of the available deep lagoon habitat is located within its boundaries.

Previous passive tracking studies indicate that giant trevally exhibit site fidelity to specific reefs over relativity long time scales (i.e., 1 to 2 years), but abandon their home ranges seasonally to undertake long distance and in some cases inter-island movements, to discrete aggregation sites presumably for reproduction (Meyer et al. 2007b; Lédée et al. 2015; Filous et al. 2017a). Although we were unable to observe these spawning related movements in our study, giant trevally are known to form large spawning aggregations (Meyer et al. 2007b; da Silva et al. 2015) and the efficacy of MPA's for this species can be enhanced by incorporating these aggregation sites within their boundaries (De Mitcheson and Erisman 2012; Russell et al. 2012). Collectively, this body of evidence suggests that the utility of spatial protections for giant trevally is dependent on the scale of protection and conservation objectives of the management entity. Given their mobility, if the complete protection of giant trevally is desired, MPAs could be an effective tool for the conservation of this species if they are implemented on the scale of the entire atoll (Meyer et al. 2007b; Filous et al. 2017b). However, if the objective is not full-scale protection, but rather the management of catch-andrelease recreational fisheries, then the relatively small size of giant trevally core use areas within their home ranges indicates that small closures, like that employed at Tetiaroa, could help reduce fishing pressure on individuals within their home ranges and spawning aggregations if properly sited. In this scenario, a temporal rotation of small spatial closures could be effective in regulating the angling pressure imposed on giant trevally, provided post release mortality is minimized (Bartholomew and Bohnsack 2005; Lewin et al. 2006; Armstrong et al. 2013).

Most giant trevally recreational fisheries adopt catch-and-release practices, but we know nothing about post-release survival rates beyond this study, in which all five animals survived. All of these fish were hooked in the corner of the jaw, suggesting fly-fishing may be a conservative way to effectively catch and release these fish, but our sample size is too small to make definitive conclusions and further research is needed to determine how factors such as gear type, hook placement, fight time, and the angler's treatment of the fish affect their survival rates (Cooke and Philipp 2004; Cooke and Cowx 2006; Danylchuk et al. 2007; Lennox et al. 2017). Numerous physiologic changes from increased exercise, air exposure and tissue damage as a result of interactions with fishing gear can result in mortality (Brownscombe et al. 2013, 2015). Large predators such as giant trevally are inherently rarer than species at lower trophic levels (Purvis et al. 2000), and in the event that anglers mishandle fish by damaging the gills, fighting them to extreme exhaustion, or exposing them to air for extended periods of time while taking photos, they could negatively impact survival and alter population viability in a specific location (Sims and Danylchuk 2017). Furthermore, post release predation is an important consideration in the management of these fisheries. Other predators at Tetiaroa that could potentially threaten the survival of caught and released giant trevally include blacktip reef sharks (Carcharhinus melanopterus) and lemon sharks (Negaprion acutidens). Lennox et al. (2017) revealed that similar predator-rich coral atolls can yield high rates of post-release predation of fish released by recreational anglers, emphasizing the need for 
anglers to handle species with care and that these environments require more attention from catch-and-release science.

Effective fisheries management requires a sound understanding the space use and habitat preferences of a species (Sale et al. 2005; Grüss et al. 2011), and reef predators like giant trevally play an essential role in economic development and ecosystem function throughout the atolls of the tropical Indo-Pacific. As the popularity of this species continues to grow, recreational catch and release tourism for giant trevally could provide alternative livelihoods that improve the stability of coastal communities (Allison and Ellis 2001; Wood et al. 2013; Watson et al. 2016). However, this species is increasingly threatened by exploitation and anthropogenic development, and as a result understanding their habitat needs is essential to their conservation (Friedlander and Dalzell 2004; Friedlander et al. 2015; McLeod 2016). This study provides unique insight into the intra- and inter-individual spatial demands of giant trevally, and ultimately, shows that giant trevally can range widely throughout their respective atolls but occupy relatively small core use areas that coincide with the interface between lagoon and shallow water habitats. These data could be applied to developing conservation plans and fisheries management tactics for this species by assisting in MPA site selection, identification of spatial size requirements and the inclusion of critical habitats in similar atolls throughout the region.

\section{ACKNOWLEDGMENTS}

We gratefully acknowledge the assistance of Teihotu Brando, who taught A.F. how to navigate Tetiaroa atoll and provided in depth local knowledge and logistical support that was instrumental to the success of this research. We thank Hinano Bagnis for providing logistic support to this research and taking care of A.F. while he was in French Polynesia. Furthermore, we would like to acknowledge the support of the Tetiaroa Society and Mathew Mchugh from Fly Odyssey who provided extensive support and funding for this project. Finally, we would like to thank anglers Mike Youkee and Johnathan Hay for capturing the giant trevally and contributing to this research. A. Danylchuk is supported by the National Institute of Food \& Agriculture, U.S. Department of Agriculture, the Massachusetts Agricultural Experiment Station, and Department of Environmental Conservation and is also a Bonefish \& Tarpon Trust Research Fellow.

\section{REFERENCES}

Afonso, P., J. Fontes, K.N. Holland, R.S. Santos (2009). Multi-Scale Patterns of Habitat Use in a Highly Mobile Reef Fish, the White Trevally Pseudocaranx dentex, and Their Implications for Marine Reserve Design. Mar Ecol Prog Ser 381:273-286. https://doi.org/10.3354/meps07946

Allison, E.H., F. Ellis (2001). The Livelihoods Approach and Management of Small-Scale Fisheries. Mar Policy 25:377-388.

Andrews, K.S., N. Tolimieri, C.J. Harvey, P.S. Levin (2011). Comparison of Fine-Scale Acoustic Monitoring Systems Using Home Range Size in Demersal Fish. Mar Biol 158(10): pp. 2377-2387. https://doi.org/10.1007/s00227-011-1724-5

Armstrong, M.P., M.J. Dean, W.S. Hoffman, D.R. Zemeckis, T.A. Nies, D.E. Pierce, P.J. Diodati, D.J. McKiernan (2013). The Application of Small Scale Fishery Closures to Protect Atlantic Cod Spawning Aggregations in the Inshore Gulf of Maine. Fish Res 141:62-69. https://doi.org/10.1016/j.fishres.2012.09.009

Bartholomew, A., J.A. Bohnsack (2005). A Review of Catch-and-Release Angling Mortality with Implications for No-Take Reserves. Rev Fish Biol Fish 15:129-154. https://doi.org/10.1007/s11160-005-2175-1

Börger, L., B.D. Dalziel, J.M. Fryxell (2008). Are There General Mechanisms of Animal Home Range Behaviour? A Review and Prospects for Future Research. Ecol Lett 11:637-650. 
https://doi.org/10.1111/j.1461-0248.2008.01182.x

Brown, J.L., G.H. Orians (1970). Spacing Patterns in Mobile Animals. Annu Rev Ecol Syst 1:239-262. https://doi.org/10.1146/annurev.es.01.110170.001323

Brownscombe, J.W., J.D. Thiem, C. Hatry, F. Cull, C.R. Haak, A.J. Danylchuk, S.J. Cooke (2013). Recovery Bags Reduce Post-Release Impairments in Locomotory Activity and Behavior of Bonefish (Albula spp.) Following Exposure to Angling-Related Stressors. J Exp Mar Bio Ecol 440:207-215. https://doi.org/10.1016/j.jembe.2012.12.004

Brownscombe, J.W., L.P. Griffin, T. Gagne, C.R. Haak, S.J. Cooke, A.J. Danylchuk (2015). Physiological Stress and Reflex Impairment of Recreationally Angled Bonefish in Puerto Rico. Environ Biol Fishes 98:2287-2295. https://doi.org/10.1007/s10641-015-0444-y

Burt, W.H. (1943). Territoriality and Home Range Concepts as Applied to Mammals. Am Soc Mammal 24:346-352.

Cooke, S.J., I.G. Cowx (2006). Contrasting Recreational and Commercial Fishing: Searching for Common Issues to Promote Unified Conservation of Fisheries Resources and Aquatic Environments. Biol Conserv 128:93-108. https://doi.org/10.1016/j.biocon.2005.09.019

Cooke, S.J., D.P. Philipp (2004). Behavior and Mortality of Caught-and-Released Bonefish (Albula spp.) in Bahamian Waters with Implications for a Sustainable Recreational Fishery. Biol Conserv 118:599-607. https://doi.org/10.1016/j.biocon.2003.10.009

Cooper, W.E. (1978). Home Range Criteria Based on Temporal Stability of Areal Occupation. J Theor Biol 73:687-695.

Crossin, G.T., M.R. Heupel, C.M. Holbrook, N.E. Hussey, S.K. Lowerre-Barbieri, V.M. Nguyen, G.D. Raby, S.J. Cooke (2017). Acoustic Telemetry and Fisheries Management. Ecol Appl 27:1031-1049. https://doi.org/10.1002/eap.1533

da Silva, I.M., T. Hempson, N.E. Hussey (2015). Giant Trevally Spawning Aggregation Highlights Importance of Community Fisheries Management No-Take Zone. Mar Biodivers 45:139-140. https://doi.org/10.1007/s12526-014-0235-2

Danylchuk, S.E., A.J. Danylchuk, S.J. Cooke, T.L. Goldberg, J. Koppelman, D.P. Philipp (2007). Effects of Recreational Angling on the Post-Release Behavior and Predation of Bonefish (Albula vulpes): The Role of Equilibrium Status at the Time of Release. $J$ Exp Mar Bio Ecol 346:127-133. https://doi.org/10.1016/j.jembe.2007.03.008

De Mitcheson, Y.S., B. Erisman (2012). Fishery and Biological Implications of Fishing Spawning Aggregations, and the Social and Economic Importance of Aggregating Fishes. In Reef Fish Spawning Aggregations: Biology, Research and Management, Fish \& Fisheries Series 35, ed. Y.S. De Mitcheson and P.L. Colin. Springer Science+Business Media.

Donaldson, M.R., S.G. Hinch, C.D. Suski, A.T. Fisk, M.R. Heupel, S.J. Cooke (2014). Making Connections in Aquatic Ecosystems with Acoustic Telemetry Monitoring. Front Ecol Environ 12:565-573. https://doi.org/10.1890/130283

Espinoza, M., T.J. Farrugia, D.M. Webber, F. Smith, C.G. Lowe (2011). Testing a New Acoustic Technique to Quantify Fine-Scale, Long-Term Fish Movements. Fish Res 108:364-371.

Filous, A., A. Friedlander, B. Wolfe, K. Stamoulis, S. Scherrer, A. Wong, K. Stone, R. Sparks (2017b). Movement Patterns of Reef Predators in a Small Isolated Marine Protected Area with Implications for Resource Management. Mar Biol 164(2). https://doi.org/10.1007/s00227-016-3043-3

Friedlander, A., P. Dalzell (2004). A Review of the Biology and Fisheries of Two Large Jacks, Ulua (Caranx ignobilis) and Omilu (Caranx melampygus), in the Hawaiian Archipelago. In Proceedings of the 2001 Fisheries Symposium, spons. American Fisheries Society, Hawai’i Chapter, pp. 171-187.

Friedlander, A.M., E.E. DeMartini (2002). Contrasts in Density, Size, and Biomass of Reef Fishes between the Northwestern and the Main Hawaiian Islands: The Effects of Fishing Down Apex Predators. Mar Ecol Prog Ser 230:253-264. https://doi.org/10.3354/meps230253

Friedlander, A.M., J. Nowlis, H. Koike (2015). Stock Assessments Using Reference Points and Historical Data: Stock Status and Catch Limits. In Marine Historical Ecology to Conservation: Applying the Past to Manage for the Future, ed. J.N. Kittinger, L.E. McClenachan, K. Gedan, L.K. Blight, pp. 91-118. 
University of California Press.

Gibson, A.J.F., E.A. Halfyard, R.G. Bradford, M.J.W. Stokesbury, A.M. Redden, J.M. Jech (2015). Effects of Predation on Telemetry-Based Survival Estimates: Insights from a Study on Endangered Atlantic Salmon Smolts. Can J Fish Aquat Sci 72:728-741. https://doi.org/10.1139/cjfas-2014-0245

Grüss, A., D.M. Kaplan, S. Guénette, C.M. Roberts, L.W. Botsford (2011). Consequences of Adult and Juvenile Movement for Marine Protected Areas. Biol Conserv 144:692-702. https://doi.org/10.1016/j.biocon.2010.12.015

Hammerschlag, N., A.C. Broderick, J.W. Coker, M.S. Coyne, M. Dodd, M.G. Frick, M.H. Godfrey, B.J. Godley, D.B.B. Griffin, K. Hartog, S.R. Murphy, T.M. Murphy, E. Rose Nelson, K.L. Williams, M.J. Witt, L.A. Hawkes (2015). Evaluating the Landscape of Fear between Apex Predatory Sharks and Mobile Sea Turtles across a Large Dynamic Seascape. Ecology 96:2117-2126. https://doi.org/10.1890/14-2113.1

Hardin, G. (1960). The Competitive Exclusion Principle Published. Am Assoc Adv Sci 131:1292-1297.

Heithaus, M.R., I.M. Hamilton, A.J. Wirsing, L.M. Dill (2006). Validation of a Randomization Procedure to Assess Animal Habitat Preferences: Microhabitat Use of Tiger Sharks in a Seagrass Ecosystem. J Anim Ecol 75:666-676. https://doi.org/10.1111/j.1365-2656.2006.01087.x

Heithaus, M.R., A. Frid, A.J. Wirsing, B. Worm (2008). Predicting Ecological Consequences of Marine Top Predator Declines. Trends Ecol Evol 23:202-2010. https://doi.org/10.1016/j.tree.2008.01.003

Heupel, M.R., C.A. Simpfendorfer, R.E. Hueter (2004). Estimation of Shark Home Ranges Using Passive Monitoring Techniques. Environ Biol 71:135-142. https://doi.org/10.1023/B:EBFI.0000045710.18997.f7

Heupel, M.R., J.M. Semmens, A.J. Hobday (2006). Automated Acoustic Tracking of Aquatic Animals: Scales, Design and Deployment of Listening Station Arrays. Mar Freshw Res 57:1-13. https://doi.org/10.1071/MF05091

Holland, K.N., B.M. Wetherbee, C.G. Lowe, C.G. Meyer (1999). Movements of Tiger Sharks (Galeocerdo cuvier) in Coastal Hawaiian Waters. Mar Biol 134:665-673. https://doi.org/10.1007/s002270050582

Karplus, I. (1978). A Feeding Association between the Grouper Epinephelus fasciatus and the Moray Eel Gymnothorax griseus. Copeia 1978:4-5.

Kramer, D.L., M.R. Chapman (1999). Implications of Fish Home Range Size and Relocation for Marine Reserve Function. Environ Biol Fishes 55:65-79. https://doi.org/10.1023/a:1007481206399

Lédée, E.J.I., M.R. Heupel, A.J. Tobin, C.A. Simpfendorfer (2015). Movements and Space Use of Giant Trevally in Coral Reef Habitats and the Importance of Environmental Drivers. Anim Biotelemetry 3:114. https://doi.org/10.1186/s40317-015-0024-0

Lennox, R.J., A. Filous, S.C. Danylchuk, S.J. Cooke, J.W. Brownscombe, A.M. Friedlander, A.J. Danylchuk (2017). Factors Influencing Postrelease Predation for a Catch-and-Release Tropical Flats Fishery with a High Predator Burden. N Am J Fish Manag 37(5):1045-1053.

Lennox, R.J., C. Engler-Palma, K. Kowarski, A. Filous, R. Whitlock, S.J. Cooke, M. Auger-Méthé (2018). Optimizing Marine Spatial Plans with Animal Tracking Data. Can J Fish Aquat Sci 13:1-13. https://doi.org/10.1139/cjfas-2017-0495

Lewin, W.C., R. Arlinghaus, T. Mehner (2006). Documented and Potential Biological Impacts of Recreational Fishing: Insights for Management and Conservation. Rev Fish Sci 4:305-367.

Losey, G.S. (1978). The Symbiotic Behavior of Fishes. In The Behavior of Fish and Other Aquatic Animals, ed. D. Mostofsky, pp. 1-31. New York: Academic Press.

McLeod, P. (2016). GT: A Flyfisher's Guide to Giant Trevally. Ludlow, UK: Merlin Unwin Books.

Meyer, C.G., K.N. Holland (2005). Movement Patterns, Home Range Size and Habitat Utilization of the Bluespine Unicornfish, Naso unicornis (Acanthuridae) in a Hawaiian Marine Reserve. Environ Biol Fishes 73:201-210. https://doi.org/10.1007/s10641-005-0559-7

Meyer, C.G., R.R. Honebrink (2005). Transintestinal Expulsion of Surgically Implanted Dummy Transmitters by Bluefin Trevally_-Implications for Long-Term Movement Studies. Trans Am Fish Soc 134:602-606. https://doi.org/10.1577/T04-082.1

Meyer, C.G., Y.P. Papastamatiou, K.N. Holland (2007a). Seasonal, Diel, and Tidal Movements of Green Jobfish (Aprion virescens, Lutjanidae) at Remote Hawaiian Atolls: Implications for Marine Protected 
Area Design. Mar Biol 151:2133-2143. https://doi.org/10.1007/s00227-007-0647-7

Meyer, C.G., K.N. Holland, Y.P. Papastamatiou (2007b). Seasonal and Diel Movements of Giant Trevally Caranx ignobilis at Remote Hawaiian Atolls: Implications for the Design of Marine Protected Areas. Mar Ecol Prog Ser 333:13-25. https://doi.org/10.3354/meps333013

Moffitt, E.A., L.W. Botsford, D.M. Kaplan, M.R. O’Farrell (2009). Marine Reserve Networks for Species That Move within a Home Range. Ecol Appl 19:1835-1847. https://doi.org/10.1890/08-1101.1

Morrissey, J.F., S.H. Gruber, S. Copeia, N. May (2009). Home Range of Juvenile Lemon Sharks, Negaprion brevirostris. Copeia 1993(2):425-434.

Ormond, R.F. (1980). Aggressive Mimicry and Other Interspecific Feeding Associations among Red Sea Coral Reef Predators. J Zool 191:247-262.

Papastamatiou, Y.P., C.G. Lowe, J.E. Caselle, A.M. Friedlander (2009). Scale-Dependent Effects of Habitat on Movements and Path Structure of Reef Sharks at a Predator-Dominated Atoll. Ecology 90:996-1008. https://doi.org/10.1890/08-0491.1

Papastamatiou, Y.P., A.M. Friedlander, J.E. Caselle, C.G. Lowe (2010). Long-Term Movement Patterns and Trophic Ecology of Blacktip Reef Sharks (Carcharhinus melanopterus) at Palmyra Atoll. J Exp Mar Bio Ecol 386:94-102. https://doi.org/10.1016/j.jembe.2010.02.009

Randall, J. (2005). Reef and Shore Fishes of the South Pacific: New Caledonia to Tahiti and the Pitcairn Islands. Honolulu: University of Hawai'i Press.

Roberts, C.M., N.V.C. Polunin (1991). Are Marine Reserves Effective in Management of Reef Fisheries? Rev Fish Biol Fish 1:65-91. https://doi.org/10.1007/BF00042662

Roberts, C.M., C.J. McClean, J.E.N. Veron, J.P. Hawkins, G.R. Allen, D.E. McAllister, C.G. Mittermeier, F.W. Schueler, M. Spalding, F. Wells, C. Vynne, T.B. Werner (2002). Marine Biodiversity Hotspots and Conservation Priorities for Tropical Reefs. Science 295:1280-1284. https://doi.org/10.1126/science.1067728

Ross, S.T. (2018). Resource Partitioning in Fish Assemblages: A Review of Field Studies. Copeia 1986:352388. http://www.jstor.org/stable/1444996

Russell, M.W., B.E. Luckhurst, K.C. Lindeman (2012). Management of Spawning Aggregations. In Reef Fish Spawning Aggregations: Biology, Research and Management, ed. Y. Sadovy de Mitcheson, L.P. Colin, pp. 371-404. Heidelberg, Germany: Springer Verlag.

Sale, P.F. (2006). Coexistence of Coral Reef Fishes - A Lottery for Living Space. Environ Biol Fishes 3(1):85102.

Sale, P.F., R.K. Cowen, B.S. Danilowicz, G.P. Jones, J.P. Kritzer, K.C. Lindeman, S. Planes, N.V.C. Polunin, G.R. Russ, Y.J. Sadovy, R.S. Steneck (2005). Critical Science Gaps Impede Use of No-Take Fishery Reserves. Trends Ecol Evol 20:74-80. https://doi.org/10.1016/j.tree.2004.11.007

Sims, B., A.J. Danylchuk (2017). Characterizing Information on Best Practice Guidelines for Catch-andRelease in Websites of Angling-Based Non-Government Organizations in the United States. Fish Res 186:688-692. https://doi.org/10.1016/j.fishres.2016.09.019

Strand, S. (1988). Following Behavior: Interspecific Foraging Associations among Gulf of California Reef Fishes. Copeia 1988:351-357.

Sudekum, A., J.D. Parrish, S. Ralston (1991). Life History and Ecology of Large Jacks in Undisturbed, Shallow, Oceanic Communities. Fish Bull 89:493-513.

Voegeli, F.A., M.J. Smale, D.M. Webber, Y. Andrade, R.K. O’dor (2001). Ultrasonic Telemetry, Tracking and Automated Monitoring Technology for Sharks. Environ Biol Fishes 60:267-281. https://doi.org/10.1023/A:1007682304720

Watson, M.S., D.C. Claar, J.K. Baum (2016). Subsistence in Isolation: Fishing Dependence and Perceptions of Change on Kiritimati, the World's Largest Atoll. Ocean Coast Manag 123:1-8.

Wetherbee, B.M., K.N. Holland, C.G. Meyer, C.G. Lowe (2004). Use of a Marine Reserve in Kaneohe Bay, Hawaii by the Giant Trevally, Caranx ignobilis. Fish Res 67:253-263. https://doi.org/10.1016/j.fishres.2003.11.004

Wolfe, B.W., C.G. Lowe (2015). Movement Patterns, Habitat Use and Site Fidelity of the White Croaker (Genyonemus lineatus) in the Palos Verdes Superfund Site, Los Angeles, California. Mar Environ Res 
109:69-80. https://doi.org/10.1016/j.marenvres.2015.06.002

Wood, A.L., J.R.A. Butler, M. Sheaves, J. Wani (2013). Sport Fisheries: Opportunities and Challenges for Diversifying Coastal Livelihoods in the Pacific. Mar Policy 42:305-314. https://doi.org/10.1016/j.marpol.2013.03.005 